\title{
Shrub regrowth, antiherbivore defenses, and nutritional value following fire
}

\author{
JASON R. SCHINDLER, TIMOTHY E. FULBRIGHT, AND T. D. A. FORBES
}

Authors are Wildlife Biologist, Blanton \& Associates, Inc., Austin, Tex.; Meadow's Professor, Caesar Kleberg Wildlife Research Institute, MSC 2I8, Tex. A\&M University-Kingsville, Kingsville, Tex. 78363; and Associate Professor, Texas A\&M University Agricultural Research and Extension Center, 1619 Garner Field Road, Uvalde, Tex. 78801 .

At the time of the research, Schindler was graduate research assistant and Fulbright was Chair and Professor, Department of Animal \& Wildlife Sciences, Texas A\&M University-Kingsville, Kingsville, Tex. Send reprint requests to Fulbright.

\section{Abstract}

Prescribed fire is a commonly used as a follow-up procedure to mechanical top growth removal methods such as mowing and roller chopping, but the effects of fire on spinescence and tannin content of shrub sprouts produced after mechanical top growth removal are unknown. Following mowing, (1) height, spinescence, and tannin content in sprouts produced after burning; (2) nutrient and fiber contents in sprouts of the 3 study species; and (3) utilization of sprouts of each species in burned and unburned plots were determined in each of blackbrush acacia (Acacia rigidula Benth.), honey mesquite (Prosopis glandulosa Torr.), and spiny hackberry (Celtis pallida Torr.). Averaged across sampling periods, burned blackbrush acacia and honey mesquite had 54\% and $94 \%$, respectively, shorter thorns than unburned plants. Burned and unburned spiny hackberry plants had similar thorn lengths. Averaged across species, sprouts of burned plants had similar tannin levels as unburned plants 6 and 12 weeks after burning. Sprouts of burned blackbrush acacia had higher levels of tannin than sprouts of unburned plants 34 weeks after burning. Leaf material from sprouts of burned spiny hackberry plants had higher crude protein and digestible protein than leaf material from unburned plants. Blackbrush acacia sprouts in burned plots contained lower digestible dry matter and digestible energy than plants in unburned plots. Honey mesquite sprouts in burned plots contained higher digestible dry matter and digestible energy than plants in unburned plots. Burning appears to be a desirable follow-up treatment to mowing because it temporarily increases nutritional value of shrub sprouts, decreases physical defenses, and suppresses growth of shrub species that have low palatability to white-tailed deer.

Key Words: Acacia rigidula, blackbrush acacia, brush management, Celtis pallida, mowing, southern Texas, spiny hackberry, white-tailed deer
Research was funded by the Rob and Bessie Welder Wildlife Foundation and the Caesar Kleberg Foundation for Wildlife Conservation. The authors thank Dr. J. Alfonso Ortega-S for translating the abstract. This is Rob and Bessie Welder Wildlife Foundation manuscript number 598 and Caesar Kleberg Wildlife Research Institute manuscript number 02-113.

Manuscript accepted 13 Jun. 03.

\section{Resumen}

El uso de quemas prescritas es una practica común después de realizar tratamientos mecánicos a la vegetación tales como chapoleos y roleos, sin embargo no existe información disponible sobre el contenido de taninos y la cantidad de espinas en los rebrotes producidos de después del tratamiento mecánico. Después del chapoleo se evaluó (1) la altura, la cantidad de espinas y el contenido de taninos en los rebrotes producidos después de la quema, (2) el contenido de nutrimentos y fibra en los rebrotes; y (3) la utilización de rebrotes de chaparro prieto (Acacia ridigula Benth.), mezquite (Prosopis glandulosa Torr.), y granjeno (Celtis palida Torr.) en áreas quemadas y sin quemar. Los arbustos chaparro prieto y mesquite en áreas quemadas en promedio para los periodos de muestreo presentaron espinas mas cortas comparados con las áreas no quemadas con 54 y $94 \%$, respectivamente. No existió diferencia en el tamaño de las espinas para granjeno entre áreas quemadas y sin quemar. Los contenidos de taninos en promedio para las especies involucradas en el estudio fue similar en áreas quemadas y sin quemar a la 6 y 12 semanas después de la quema. La digestibilidad y la proteína cruda de las hojas de granjeno fue superior en plantas quemadas. El contenido de materia seca digestible y energía digestible en los rebrotes de chaparro prieto fue menor en las áreas quemadas comparados con las no quemadas, mientras que en el caso de mezquite los resultados fueron inversos. El uso de quema prescrita después del chapoleo incrementa temporalmente el valor nutricional del rebrote de los arbustos, reduce la tamaño de las espinas de las plantas y el crecimiento de las especies de arbustos con baja palatabilidad para el venado cola blanca.

Prescribed fire is commonly used as a follow-up procedure to mechanical top growth removal methods such as mowing and roller chopping to maintain suppression and elevated nutrient contents of woody plants and to increase production of forbs and grasses (Scifres and Hamilton 1993). Fire is used as follow-up maintenance rather than as the initial treatment because dense stands of brush inhibit production of adequate fine fuel to carry fires. Effects of fire on spinescence and tannin content of shrub sprouts produced after top growth removal are unknown.

Damage to plant tissue stimulates responses to prevent further damage, including physical deterrence, e.g. spines and thorns (Campbell 1986, Young 1987, Milewski et al. 1991, Rohner and Ward 1997, Cooper and Ginnett 1998), digestion-inhibiting and toxic chemicals (Cooper and Owen-Smith 1985, Clausen et al. 
1990, Stock et al. 1993, Forbes et al. 1995), and low nutritional quality (Mattson 1980, Lundberg and Åström 1990). Branches of African acacia trees that have been browsed by large herbivores produce longer thorns and a greater density of thorns than do inaccessible branches on the same trees (Young 1987, Milewski et al. 1991). Blackbrush acacia (Acacia rigidula Benth.) plants on sites that have been roller chopped have longer thorns and a greater density of thorns than plants on untreated sites for 9 years after roller chopping (Schindler 2000). Multiple top growth removal treatments further enhance spinescence. Long thorns deter large herbivores by decreasing bite sizes and biting rates (Cooper and Owen-Smith 1986, Belovsky and Schmitzet al. 1991, Gowda 1996). Thorns on blackbrush acacia plants also reduce foraging efficiency by small mammals (Cooper and Ginnett 1998).

Tannins are common throughout the plant kingdom and reduction of availability of protein and other nutrients is well documented (Robbins et al. 1987a, Robbins et al. 1987b, Lundberg and Åstrom 1990, Hagerman et al. 1992) by protecting plant cell walls from decomposition and inactivating digestive enzymes (Cooper and Owen-Smith 1985). Changes in fiber, nutrients, and digestibility after top growth removal have been extensively researched (Everitt 1983, Reynolds et al. 1992, Ruthven and Hellgren 1995), but not in conjunction with tannin contents. Reynolds et al. (1992) found that roller chopping in early July temporarily increased crude protein content but decreased in vitro organic matter digestibility of blackbrush acacia, which may decrease digestible protein and energy. Ruthven and Hellgren (1995) reported lower in vitro dry matter digestibility of honey mesquite (Prosopis glandulosa Torr.) and spiny hackberry (Celtis pallida Torr.) leaves 17 years after root plowing, but neutral detergent fiber was similar between treatments. These studies suggest that factors other than nutrient and fiber contents reduce digestibility of woody species and affect white-tailed deer (Odocoileus virginianus Raf.) forage for years after brush management.

Blackbrush acacia, honey mesquite, and spiny hackberry are widespread in the southwestern United States and northern Mexico and are important in white-tailed deer diets (Arnold and Drawe 1979, Meyer et al. 1984, Ramirez et al. 1996, Ramirez and Ledezma-Torres (1997). Based on the increases in plant physical and chemical defenses after tissue damage discussed above, the hypothesis that burning sprouts of blackbrush acacia, honey mesquite, and spiny hackberry plants produced after mowing results in production of new sprouts that are more heavily defended by thorns and tannins than unburned sprouts was tested. Since browsing mammals avoid forages with higher concentrations of defensive chemicals, regardless of nutrient contents (Bryant and Kuropat 1980, Bryant 1981, Basey et al. 1988, Cooper et al. 1988, Singer et al. 1994, Woodward and Coppock 1995), the investigators predicted that white-tailed deer would browse sprouts on burned plants less than unburned sprouts. Specific objectives were to determine (1) height, spinescence, and tannin content of blackbrush acacia, honey mesquite, and spiny hackberry sprouts after burning; (2) fiber and nutrient contents in sprouts of the 3 study species; and (3) utilization by whitetailed deer of sprouts produced by burned and unburned plants of each species.

\section{Materials and Methods}

\section{Study Area}

The study was conducted on the Rob and Bessie Welder Wildlife Foundation Refuge, which consists of 3,158 ha of native rangeland $70 \mathrm{~km}$ north of Corpus Christi in San Patricio County, Tex. $\left(28^{\circ}\right.$ $\left.6^{\prime} 49^{\prime \prime} \mathrm{N}, 97^{\circ} 25^{\prime} 00^{\prime \prime} \mathrm{W}\right)$. The refuge lies adjacent to the Aransas River at about 12 $\mathrm{m}$ above sea level, with a slope gradient $<$ $1 \%$. The climate is characterized as subtropical with hot summers and mild winters. The average annual maximum and minimum temperatures (1982-1998) were 27 and $17^{\circ} \mathrm{C}$, respectively. Average length of the frost-free growing season was 300 days. Average annual rainfall (1956-1998) recorded on the refuge was $89 \mathrm{~cm}$, with bimodal peaks occurring in spring and fall (Rob and Bessie Welder Wildlife Foundation, Sinton, Tex., Refuge Census Records, 1956-1999). Rainfall during the study (August 1998 to March 1999) was $92 \mathrm{~cm}$.

Two major plant communities were present in the study area: a chaparral-mixed grass community, with a variety of dominant shrub species, and a live oak-chaparral community dominated by live oak (Quercus virginiana Mill.), with a shrub community similar in species composition to the chaparral-mixed grass community (Drawe et al. 1978). From 1965 to 1998 , overall shrub canopy cover in untreated sites in the study area increased from about 46\% (Box and Powell 1965) to about $71 \%$. Soils included Victoria clay (Udic Pellustert), Papalote fine sandy loam (Aquic Paleustalf), Orelia fine sandy loam (Typic Ochraqualf), and Orelia sandy clay loam (Typic Ochraqualf) (Guckian and Garcia 1979). The study area averaged $26 \pm 3(\overline{\mathrm{x}} \pm \mathrm{SE}, n=21)$ individual white-tailed deer $\mathrm{km}^{-2}$ (Rob and Bessie Welder Wildlife Foundation, Sinton, Tex., Refuge Records, 1975-1995).

\section{Experimental Design}

A randomized complete block design with 2 treatments (burned versus unburned) and 3 species was used to test predictions. Each of 5 blocks (replicates) consisted of a 4-ha $(100 \times 400 \mathrm{~m})$ plot that was roller chopped in 1989 and in 1995 and mowed in March 1998. Prior to mowing in March 1998 , overall shrub density in the study plots averaged 7,633 $\pm 2,442$ plants ha $^{-1}$, and overall shrub canopy cover averaged $33 \pm 6 \%$ (Schindler 2000). Since these plants had been roller chopped twice and mowed once, many had multiple stems. Each block was subdivided into two, 2-ha $(100 \times 200 \mathrm{~m})$ plots. One of the 2 plots within each block was randomly burned, and the remaining plot was left unburned. Within each burned and unburned plot, blackbrush acacia, honey mesquite, and spiny hackberry plants were caged to prevent browsing by white-tailed deer, and comparable plants of each species were marked and left unprotected.

\section{Fire Treatment}

Prescribed burns were described by weather conditions (relative humidity, wind speed and direction, and air temperature), burning conditions (fuel type, quantity, and moisture), and intensity of fire (heat of combustion, rate of spread, fuel consumption, maximum flame height). These measurements were documented before, during, and after each prescribed burn. Fuel type, quantity, and moisture were determined by sampling five, 0.25 $\mathrm{m}^{2}$ quadrats randomly placed in each plot. Fuel was divided into 4 categories. Three of these categories were described in Masters and Engle (1994): (1) 1-hour fuels (standing and horizontal dry material $\leq 0.6$ $\mathrm{cm}$ in diameter), (2) 10-hour fuels (standing and horizontal dry material between 0.6 and $2.5 \mathrm{~cm}$ in diameter), and (3) green herbaceous materials. Woody materials $\geq$ $2.5 \mathrm{~cm}$ burn slowly and were not considered fuel. A fourth category consisting of green woody materials $<2.5 \mathrm{~cm}$ was included in this study. All fuels were weighed, dried at $50^{\circ} \mathrm{C}$ to constant mass, 
and reweighed to determine fuel moisture and dry fuel load. Fire intensity was calculated using Byram's (1959) equation:

$$
I=h w r,
$$

where $I$ is frontal fire intensity $\left(\mathrm{kW} \mathrm{m}^{-1}\right), h$ is net heat of combustion $\left(\mathrm{kJ} \mathrm{kg}^{-1}\right), w$ is fuel consumed $\left(\mathrm{kg} \mathrm{m}^{-2}\right)$, and $r$ is rate of spread $\left(\mathrm{m} \mathrm{sec}^{-1}\right)$. Heat of combustion was estimated by combusting dried and ground fuel samples in a Parr adiabatic bomb calorimeter. Residual fuel from five, 0.25 $\mathrm{m}^{2}$ quadrats randomly placed in each burned plot was collected, weighed, dried at $50^{\circ} \mathrm{C}$ to constant mass, and reweighed to determine fuel consumption by the fires. Rate of spread was determined by timing headfires across three, $10-\mathrm{m}$ intervals and timing backfires across one, 5-m interval. After burning, 15 plants of each study species in each burned and unburned plot were marked, and the percentage that had not sprouted 1 year after burning was recorded to determine mortality caused by the fires.

\section{Sample Collection and Analysis}

After burning, a circular 1.25 -m diameter wire cage was placed around each of 3 randomly selected plants of each species in each of the 5 burned plots and 5 unburned plots to prevent browsing by herbivores. Three plants of comparable size (visually estimating height, basal diameter, and number of stems) of each species nearest each wire cage were marked and left unprotected. Six weeks after burning, regrowth from caged and uncaged plants in burned and unburned plots was sampled. Maximum height of regrowth was measured to the nearest $\mathrm{mm}$. The terminal $5 \mathrm{~cm}$ from 3 random sprouts was collected and placed on dry ice, stored in a freezer, freeze-dried, and separated into leaves, stems, and thorns. Densities of thorns were determined by counting the number of each per $5 \mathrm{~cm}$; maximum length of all thorns $>1 \mathrm{~mm}$ (Rohner and Ward 1997) was measured to $0.01 \mathrm{~mm}$ with a digimatic caliper; and leaf, stem, and thorn biomass were measured to 0.1 mg. All remaining non-lignified regrowth was collected, placed on dry ice, and stored at $-35^{\circ} \mathrm{C}$ until samples were freeze-dried and ground through a $1-\mathrm{mm}$ screen for chemical analysis. Wire cages were moved to 3 new plants of each species, and 3 new plants of each species nearest the cages were marked and left unprotected. Sampling of regrowth from caged and uncaged plants in burned and unburned plots was repeated 12 and 34 weeks after burning.
Nitrogen (N) content of leaves was determined in a LECO CHN-1000 Carbon Hydrogen Nitrogen Analyzer. Percent crude protein (CP) was estimated by $\mathrm{N} x$ 6.25. Neutral detergent fiber (NDF), acid detergent fiber (ADF), and acid detergent lignin (ADL) were estimated by sequential fiber analysis (Goering and Van Soest 1970) using an ANKOM ${ }^{200}$ Fiber Analyzer. The protein precipitation capacity of tannins in leaves was determined using a bovine serum albumin precipitation assay (Martin and Martin 1982). This assay was used to quantify tannins because it mimics protein binding processes occurring in vivo (Robbins et al. 1987a), and it is a reliable way to determine the protein-precipitating capacity of leaf tannins (Martin and Martin 1982). Digestible protein (DP) and digestible dry matter (DDM) were estimated using equations derived for white-tailed deer (Robbins et al. 1987a, Robbins et al. 1987b). Digestible energy (DE) was estimated from DDM using an equation for browse from Robbins (1993:299). Gross energy (GE) was estimated by combusting a sample in a Parr adiabatic bomb calorimeter, and net energy (NE) was estimated by DE x GE. All values of chemical constituents were based on leaf dry matter. Percent dry matter was determined by drying a ground sample at $104^{\circ} \mathrm{C}$ for 24 hours. Chemical constituents were categorized as chemical defenses (NDF, ADF, ADL, tannins) and nutrients (CP, DP, DDM, DE, GE, and NE).

To determine if white-tailed deer herbivory suppressed growth of sprouts produced after burning, maximum height of regrowth of caged and uncaged plants within burned plots was compared using analysis of variance (ANOVA) with repeated measures for a randomized complete block design with caged treatment and species as main effects and sampling period as the repeated measures factor (SAS 1989). Tukey's honestly significant difference (HSD) test was used to separate $(\mathrm{P}<0.05)$ means when caged treatment by species interactions occurred. When interactions between sampling period and either caged treatment or species occurred, differences between caged and uncaged plants and among species within each sampling period were determined with contrasts, using the Satterthwaite approximation to calculate the degrees of freedom and corresponding standard error for the ttest (Milliken and Johnson 1984:307-308). When the 3-way interaction (sampling period by caged treatment by species) was significant, a separate ANOVA was conducted for each sampling period.
Physical measurements, chemical defenses, and nutrients from caged plants only were compared between burned and unburned plots using ANOVA with repeated measures for a randomized complete block design with burning treatment and species as main effects and sampling period as the repeated measures factor (SAS 1989) to determine the effects of burning on shrub morphology and chemistry. Tukey's HSD test was used to separate $(P<0.05)$ means when treatment by species interactions occurred. When interactions between sampling period and either treatment (burned or unburned) or species occurred, differences between burned and unburned plants and among species within each sampling period were determined with contrasts, using the Satterthwaite approximation to calculate the degrees of freedom and corresponding standard error for the t-test (Milliken and Johnson 1984:307-308). When the 3-way interaction (sampling period by burning treatment by species) was significant, a separate ANOVA was conducted for each sampling period.

\section{Utilization of Burned and \\ Unburned Sprouts}

To determine the browsing intensity by white-tailed deer of blackbrush acacia, honey mesquite, and spiny hackberry sprouts after burning compared to growth on unburned plants, 12 randomly chosen twigs on each of 5 plants of each species in each burned and unburned plot were marked 5 weeks after burning, and the number browsed was recorded biweekly for 8 weeks. Differences in herbivory of burned and unburned plants of each species were analyzed by comparing the percentage of twigs browsed every 2 weeks between burned and unburned plants and among species using a randomized complete block ANOVA with burning treatment and species as main effects for each week measured.

\section{Results}

\section{Fire Effects}

All prescribed fires were conducted between 1100 and 1600 hours on 7 Aug. 1998. Fires consumed $81 \pm 6 \%(0.95 \pm$ $0.18 \mathrm{~kg} \mathrm{~m}^{-2}$ ) of available fuels (Table 1). There was a burning treatment by species interaction $(P=0.018)$ for percentage of marked plants that had not sprouted 1 year after burning. Burning caused significant $(\mathrm{P}<0.001)$ mortality of blackbrush acacia plants but not of honey mesquite and 
Table 1. Mean values for weather conditions, fuel conditions, fire intensity, and shrub mortality on 2-ha mixed-brush sites $(n=5)$ on the Rob and Bessie Welder Wildlife Foundation Refuge, San Patricio County, Tex., 7 Aug. 1998.

\begin{tabular}{|c|c|c|}
\hline & $\overline{\mathrm{x}}$ & SE \\
\hline Minutes burned & 9.2 & 4.2 \\
\hline \multicolumn{3}{|l|}{ Weather conditions } \\
\hline Air temperature $\left({ }^{\circ} \mathrm{C}\right)$ & 34 & 1 \\
\hline Wind speed (km hour $\left.{ }^{-1}\right)$ & 12.0 & 1 \\
\hline Relative humidity (\%) & 50 & 2 \\
\hline \multicolumn{3}{|l|}{ Fuel load $\left(\mathrm{kg} \mathrm{ha}^{-1)}\right)^{1}$} \\
\hline 1-hour & 7,791 & 1,020 \\
\hline 10-hour & 1,855 & 853 \\
\hline Green herbaceous & 508 & 83 \\
\hline Green woody & 1,723 & 697 \\
\hline Heat of combustion $\left(\mathrm{kJ} \mathrm{kg}^{-1)}\right.$ ) & 18,002 & 123 \\
\hline Fuel consumption $\left(\mathrm{kg} \mathrm{m}^{-2)}\right)$ & 0.95 & 0.18 \\
\hline Rate of spread $\left(m \sec ^{-1)}\right)$ & 0.28 & 0.07 \\
\hline Maximum flame height (m) & 1.72 & 0.24 \\
\hline Fire intensity $\left(\mathrm{kW} \mathrm{m}^{-1)}\right)$ & 4,158 & 775 \\
\hline \multicolumn{3}{|l|}{ Shrub mortality ${ }^{2}$} \\
\hline Blackbrush acacia & 10 & 3 \\
\hline Honey mesquite & 3 & 2 \\
\hline Spiny hackberry & 0 & \\
\hline
\end{tabular}

Fuels consisted of 1 -hour fuels (standing and horizontal dry material $\leq 0.6 \mathrm{~cm}$ in diameter); 10 -hour fuels (standing and horizontal dry material between 0.6 and $2.5 \mathrm{~cm}$ in diameter); green herbaceous fuels (green forbs and grasses); and green woody fuels (green woody plants $<2.5 \mathrm{~cm}$ in diameter).

$\%$ of each species that had not sprouted 1 year after burning. spiny hackberry plants $(\mathrm{P}>0.05)$ compared to unburned plots. Ten $\pm 3 \%, 3 \pm$ $2 \%$, and $0 \%$ of marked blackbrush acacia, honey mesquite, and spiny hackberry plants, respectively, had not sprouted 1 year after burning. None of the marked unburned plants died during the study.

\section{Regrowth Height in Burned Plots}

Within burned plots, there was a sampling period by caged treatment by species taller than uncaged plants 6 weeks $(\mathrm{P}=$ $0.002)$ and 12 weeks $(P<0.001)$ after burning, but were similar $(P>=0.709)$ in height by 34 weeks post-fire (Fig. 1).

Since spiny hackberry plants that were unprotected were shorter than caged plants, species comparisons in burned plots were conducted for caged plants only. There was a sampling period by burning treatment by species interaction $(P$ $=0.008$ ) for regrowth height, so a separate ANOVA was conducted for each sampling period. Spiny hackberry sprouts were 1.8 to 2.6 times taller $(P<0.001)$ than blackbrush acacia and honey mesquite sprouts 6 and 12 weeks after burning (Fig. 2). Thirty-four weeks after burning, height of honey mesquite and spiny hackberry plants was similar $(P=0.623)$, and regrowth of both species was taller $(\mathrm{P}<$ 0.05 ) than regrowth produced by blackbrush acacia plants. There were no significant differences $(P>0.05)$ in height of regrowth between caged and uncaged plants or among species in plots that were unburned.

interaction $(P=0.008)$ for regrowth height $(\mathrm{mm})$, so a separate ANOVA was conducted for each sampling period. There was a caged treatment by species interaction $(P<0.001)$ for regrowth height 6 and 12 weeks after burning but not 34 weeks after burning. Caged and uncaged blackbrush acacia and honey mesquite were similar $(P>0.05)$ in height on all sampling dates. Spiny hackberry plants protected from browsing were 1.5 to 1.8 times

\section{Physical Defenses}

There was a burning treatment by species interaction $(P<0.05)$ for thorn length $(\mathrm{mm})$, thorn mass $(\mathrm{mg})$, and ratios of thorn mass to leaf mass (thorn:leaf mass), and thorn mass to stem mass (thorn:stem mass) (Table 2). Averaged across sampling periods, burned blackbrush acacia and honey mesquite plants had $94 \%$ and $54 \%$, respectively, shorter (P $<0.001)$ thorns than unburned plants.

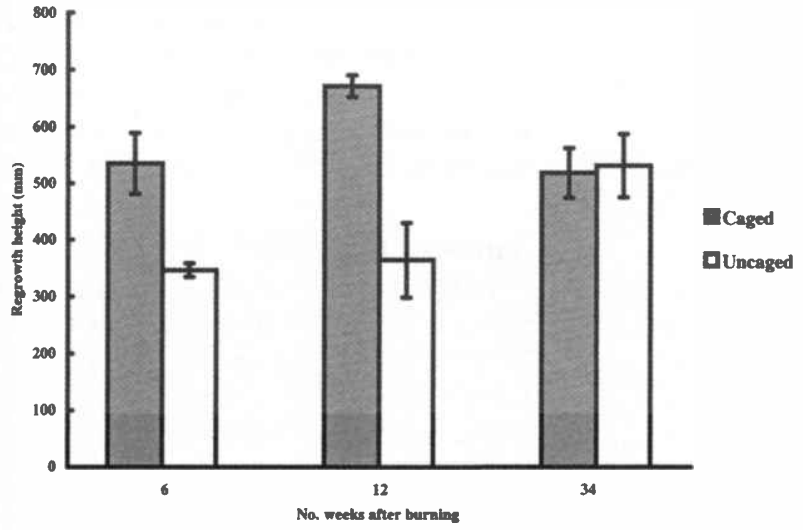

Fig. 1. Mean ( $\pm \mathrm{SE})$ height $(\mathrm{mm})$ of regrowth produced by caged and uncaged spiny hackberry (Celtis pallida Torr.) plants within burned plots 6, 12, and 34 weeks after burning in August 1998 on the Rob and Bessie Welder Wildlife Foundation Refuge, San Patricio County, Tex.

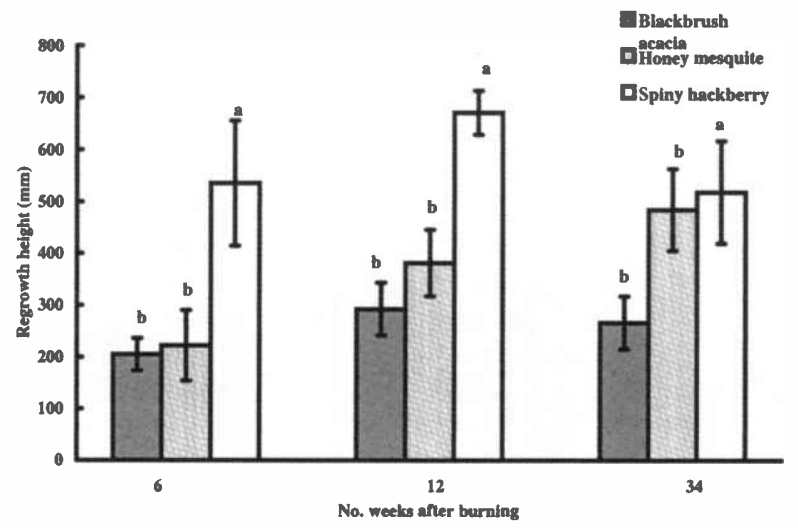

Fig. 2. Mean ( $\pm \mathrm{SE}$ ) height $(\mathrm{mm})$ of regrowth produced by caged blackbrush acacia (Acacia rigidula Benth.), honey mesquite (Prosopis glandulosa Torr.), and spiny hackberry (Celtis pallida Torr.) within burned plots 6, 12, and 34 weeks after burning $(n=5)$ in August 1998 on the Rob and Bessie Welder Wildlife Foundation Refuge, San Patricio County, Tex. Means within a sampling period with the same letter are similar ( $P$ > 0.05 , Tukey's HSD) based on analysis of variance (ANOVA) with repeated measures for a randomized complete block design with burning treatment and species as main effects and sampling period as the repeated measures factor. 
Table 2. Mean values ${ }^{1}$ of physical characteristics of blackbrush acacia (Acacia rigidula Benth.), honey mesquite (Prosopis glandulosa Torr.), and spiny hackberry (Celtis pallida Torr.) averaged across 3 sampling periods $(n=15)$ in burned and unburned plots on the Rob and Bessie Welder Wildlife Foundation Refuge, San Patricio County, Tex., 1998.

\begin{tabular}{|c|c|c|c|c|c|}
\hline \multirow[b]{2}{*}{ Species } & \multicolumn{2}{|c|}{ Burned } & \multicolumn{2}{|c|}{ Unburned } & \multirow[b]{2}{*}{$\mathbf{P}$} \\
\hline & $\overline{\mathbf{x}}$ & SE & $\overline{\mathbf{x}}$ & SE & \\
\hline \multicolumn{6}{|l|}{ Blackbrush acacia } \\
\hline Thorn length (mm) & 5.57 & 0.38 & 8.55 & 0.78 & $<0.001$ \\
\hline 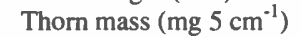 & 16.1 & 3.3 & 42.9 & 6.3 & $<0.001$ \\
\hline Thorn:leaf mass & 0.201 & 0.044 & 0.409 & 0.068 & $<0.001$ \\
\hline Thorn:stem mass & 0.441 & 0.061 & 0.793 & 0.096 & $<0.001$ \\
\hline Leaf:stem mass ${ }^{2}$ & 2.676 & 0.215 & 2.198 & 0.226 & \\
\hline \multicolumn{6}{|l|}{ Honey mesquite } \\
\hline Thorn length (mm) & 6.02 & 0.31 & 11.65 & 0.89 & $<0.001$ \\
\hline Thorn mass ( $\mathrm{mg} 5 \mathrm{~cm}^{-1}$ ) & 2.0 & 0.5 & 8.4 & 1.3 & 0.065 \\
\hline Thorn:leaf mass & 0.013 & 0.003 & 0.031 & 0.006 & 0.639 \\
\hline Thorn:stem mass & 0.040 & 0.009 & 0.093 & 0.010 & 0.102 \\
\hline Leaf:stem mass ${ }^{2}$ & 3.851 & 0.603 & 4.877 & 1.057 & \\
\hline \multicolumn{6}{|l|}{ Spiny hackberry } \\
\hline Thorn length (mm) & 6.04 & 0.36 & 6.33 & 0.35 & 0.652 \\
\hline 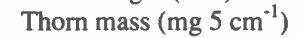 & 8.3 & 1.8 & 14.7 & 2.2 & 0.070 \\
\hline Thorn:leaf mass & 0.114 & 0.025 & 0.153 & 0.021 & 0.326 \\
\hline Thorn:stem mass & 0.241 & 0.038 & 0.389 & 0.038 & $<0.001$ \\
\hline Leaf:stem mass ${ }^{2}$ & 2.585 & 0.267 & 2.861 & 0.270 & \\
\hline
\end{tabular}

Data were analyzed using analysis of variance (ANOVA) with repeated measures for a randomized complete block design with burning treatment and species as main effects and sampling period as the repeated measures factor.

${ }^{2}$ Burning treatment by species interaction $(P=0.194)$ was not significant for leaf:stem mass. Burning treatment main effect $(P=0.408)$. Sampling period by burning treatment interaction $(P=0.603)$. Sampling period by buming treatment by species interaction $(P=0.850)$

Blackbrush acacia regrowth in burned plots had lower $(\mathrm{P}<0.001)$ thorn mass than plants in unburned plots. Averaged across sampling periods, blackbrush acacia regrowth in burned plots had lower ( $\mathrm{P}$ $<0.001)$ thorn:leaf mass and thorn:stem mass and spiny hackberry regrowth had lower $(P<0.001)$ thorn:stem mass than unburned plants. There were no significant differences $(P>0.05)$ between burned and unburned plants for leaf:stem mass.
A sampling period by burning treatment by species interaction $(P<0.05)$ existed for thorn density (no. $5 \mathrm{~cm}^{-1}$ ), so a separate ANOVA was conducted for each sampling period (Table 3). Averaged across species, regrowth of burned and unburned plants had similar $(P=0.176)$ thorn densities 6 weeks after burning. There was a burning treatment by species interaction $(\mathrm{P}<0.05)$ for thorn density 12 and 34 weeks after burning. Spiny hackberry regrowth in burned plots had lower $(P=0.004)$ thom density than unburned plants 12 weeks after burning. Density of thorns on regrowth of blackbrush acacia and honey mesquite plants was similar $(P>0.05)$ between burning treatments 12 weeks after burning. Blackbrush acacia regrowth in burned plots had lower $(P=0.001)$ thorn density than unburned plants 34 weeks after burning. Density of thorns on regrowth of honey mesquite and spiny hackberry plants was similar $(\mathrm{P}>$
0.05 ) between burning treatments 34 weeks after burning.

\section{Chemical Compostion}

There was a sampling period by burning treatment by species interaction $(\mathrm{P}=$ 0.016 ) for protein-precipitating tannins ( $\mathrm{mg}$ bovine serum albumin precipitated per g leaf dry matter), therefore a separate ANOVA was conducted for each sampling period (Table 3). Averaged across species, regrowth of burned plants had similar $(\mathrm{P}>$ $0.05)$ tannin levels to unburned plants 6 and 12 weeks after burning. There was a burning treatment by species interaction $(\mathrm{P}$ $=0.032$ ) for tannin content 34 weeks after burning. Regrowth of burned blackbrush acacia had higher $(P=0.023)$ levels of tannins than unburned plants 34 weeks after burning. Honey mesquite and spiny hackberry regrowth in burned and unburned plots had similar tannin contents $(P>0.05) 34$ weeks after burning.

There was no significant $(\mathrm{P}>0.05)$ burning treatment by species interaction for NDF (\%) (Table 4). Averaged across sampling periods and species, NDF was similar $(P=0.814)$ in leaves of burned and unburned plants. There was a burning treatment by species interaction $(P<0.05)$ for $\mathrm{ADF}(\%)$ and $\mathrm{ADL}(\%)$. Averaged across sampling periods, blackbrush acacia plants in burned plots had higher $(\mathrm{P}<$ $0.001)$ ADF than plants in unburned plots. Acid detergent fiber was similar $(P>0.05)$ between burned and unburned honey mesquite and spiny hackberry plants. Averaged across sampling periods, regrowth of burned honey mesquite plants had lower ADL than untreated plants $(\mathrm{P}<$ $0.001)$. Acid detergent lignin was similar $(P>0.05)$ between burned and unburned blackbrush acacia and spiny hackberry regrowth.

\section{Nutrient Contents}

There was a burning treatment by species interaction $(\mathrm{P}<0.01)$ for $\mathrm{CP}(\%)$, DP (\%), DDM (\%), and DE (\%) (Table 4). Leaf material from regrowth of burned spiny hackberry plants had higher $(\mathrm{P}<$ $0.001) \mathrm{CP}$ and DP than leaf material from unburned plants. Crude protein and DP were similar $(P>0.05)$ between burning treatments for blackbrush acacia and honey mesquite plants. Blackbrush acacia regrowth in burned plots contained lower $(P<0.01)$ DDM and DE than plants in unburned plots. Honey mesquite regrowth in burned plots contained higher $(\mathrm{P}=$ $0.003)$ DDM and DE than plants in unburned plots. Digestible dry matter and DE were similar $(P>0.05)$ between 
Table 3. Mean values ${ }^{1}$ of physical and chemical characteristics of blackbrush acacia (Acacia rigidula Benth.), honey mesquite (Prosopis glandulosa Torr.), and spiny hackberry (Celtis pallida Torr.) regrowth 6,12 , and 34 weeks $(n=5)$ after burning compared to plants in unburned plots on the Rob and Bessie Welder Wildlife Foundation Refuge, San Patricio County, Tex., 1998.

\begin{tabular}{|c|c|c|c|c|c|}
\hline \multirow[b]{2}{*}{ Species } & \multicolumn{2}{|c|}{ Burned } & \multicolumn{2}{|c|}{ Unburned } & \multirow[b]{2}{*}{$\mathbf{P}$} \\
\hline & $\overline{\mathrm{x}}$ & SE & $\bar{x}$ & $\mathrm{SE}$ & \\
\hline \multicolumn{6}{|l|}{6 weeks } \\
\hline \multicolumn{6}{|l|}{ Blackbrush acacia } \\
\hline Thorn density (no. $\left.5 \mathrm{~cm}^{-1}\right)^{2}$ & 11.82 & 0.55 & 11.47 & 0.45 & \\
\hline Tannin ${ }^{3,4}$ & 691.7 & 21.2 & 696.5 & 28.2 & \\
\hline \multicolumn{6}{|l|}{ Honey mesquite } \\
\hline Thorn density (no. $\left.5 \mathrm{~cm}^{-1}\right)^{2}$ & 1.51 & 0.37 & 1.67 & 0.13 & \\
\hline Tannin $^{3,4}$ & 6.7 & 4.3 & 3.6 & 1.7 & \\
\hline \multicolumn{6}{|l|}{ Spiny hackberry } \\
\hline Thorn density (no. $\left.5 \mathrm{~cm}^{-1}\right)^{2}$ & 2.62 & 0.49 & 4.60 & 0.80 & \\
\hline Tannin ${ }^{3,4}$ & 0.9 & 0.9 & 0.6 & 0.4 & \\
\hline \multicolumn{6}{|l|}{12 weeks } \\
\hline \multicolumn{6}{|l|}{ Blackbrush acacia } \\
\hline Thorn density (no. $5 \mathrm{~cm}^{-1}$ ) & 11.56 & 0.49 & 11.16 & 0.47 & 0.602 \\
\hline Tannin $^{3,5}$ & 542.7 & 23.2 & 515.6 & 36.6 & \\
\hline \multicolumn{6}{|l|}{ Honey mesquite } \\
\hline Thorn density (no. $5 \mathrm{~cm}^{-1}$ ) & 2.36 & 0.61 & 1.73 & 0.34 & 0.419 \\
\hline Tannin $^{3.5}$ & 2.2 & 1.1 & 2.6 & 1.1 & \\
\hline \multicolumn{6}{|l|}{ Spiny hackberry } \\
\hline Thorn density (no. $5 \mathrm{~cm}^{-1}$ ) & 4.87 & 0.66 & 7.31 & 0.87 & 0.004 \\
\hline Tannin $^{3,5}$ & 1.2 & 0.8 & 2.4 & 1.1 & \\
\hline \multicolumn{6}{|l|}{34 weeks } \\
\hline \multicolumn{6}{|l|}{ Blackbrush acacia } \\
\hline Thorn density (no. $5 \mathrm{~cm}^{-1}$ ) & 10.09 & 0.94 & 12.82 & 0.33 & 0.001 \\
\hline Tannin $^{3}$ & 682.1 & 33.0 & 570.0 & 50.7 & 0.023 \\
\hline \multicolumn{6}{|l|}{ Honey mesquite } \\
\hline Thorn density (no. $5 \mathrm{~cm}^{-1}$ ) & 1.62 & 0.40 & 1.09 & 0.31 & 0.467 \\
\hline Tannin $^{3}$ & 5.3 & 3.0 & 7.8 & 4.3 & 0.999 \\
\hline \multicolumn{6}{|l|}{ Spiny hackberry } \\
\hline Thorn density (no. $5 \mathrm{~cm}^{-1}$ ) & 6.00 & 0.59 & 7.22 & 0.30 & 0.105 \\
\hline Tannin $^{3}$ & 2.0 & 1.1 & 0 & & 0.999 \\
\hline
\end{tabular}

Data were analyzed using analysis of variance (ANOVA) with repeated measures for a randomized complete block design with burning treatment and species as main effects and sampling period as the repeated measures factor. There was a significant $(\mathrm{P}<0.05)$ sampling period by burning treatment by species interaction for each variable, so a separate ANOVA was conducted for each sampling period.

${ }^{2}$ Burning treatment by species interaction $(P=0.085)$ and burning treatment main effect $(P=0.176)$ were not significant for thorn density 6 weeks after burning.

${ }^{3} \mathrm{Mg}$ bovine serum albumin precipitated per $\mathrm{g}$ leaf dry matter.

${ }^{4}$ Burning treatment by species interaction $(P=0.965)$ and burning treatment main effect $(P=0.969)$ were not significant for tannin 6 weeks after burning.

${ }^{5}$ Burning treatment by species interaction $(P=0.632)$ and burning treatment main effect $(P=0.539)$ were not significant for tannin 12 weeks after burning.

burned and unburned spiny hackberry plants.

There was no burning treatment by species interaction $(P=0.180)$ for $G E$ $\left(\mathrm{kcal} \mathrm{g}^{-1}\right)$ (Table 4). Averaged across sampling periods and species, burned and unburned plants had similar $(\mathrm{P}=0.311)$ $\mathrm{GE}$ after burning. There was a burning treatment by species interaction ( $\mathrm{P}<$ $0.001)$ for NE ( $\left.\mathrm{kcal}^{-1}\right)$. Regrowth from burned blackbrush acacia plants had lower $(P=0.016) \mathrm{NE}$ than unburned plants, and regrowth from burned honey mesquite plants had higher $(P=0.013) \mathrm{NE}$ than unburned plants. Net energy was similar $(P=0.313)$ in burned and unburned spiny hackberry plants. browsed more $(\mathrm{P}<0.05)$ by white-tailed deer than blackbrush acacia and honey mesquite regrowth throughout the study (Fig. 4). Averaged across burning treatments 9 weeks after burning, spiny hackberry regrowth was utilized more by white-tailed deer than blackbrush acacia $(\mathrm{P}<0.001)$ and honey mesquite $(\mathrm{P}<$ $0.001)$ regrowth.

\section{Discussion and Conclusions}

Burning shrubs 5 months after mowing decreased spinescence in blackbrush acacia and honey mesquite sprouts for 8 months after burning, which contradicted our prediction that burning would increase physical and chemical defenses of plants. Burned blackbrush acacia plants did not invest more carbon into tannins than unburned plants until after leaves were dropped during winter and new leaves emerged in the spring. Significant plant damage after summer burning may require blackbrush acacia to allocate resources available immediately after burning into growth of photosynthetic material, with less investment into physical and chemical antiherbivore defenses.

According to the carbon-nutrient balance (CNB) hypothesis (Bryant et al. 1983, Fajer et al. 1992), in areas of low nitrogen fertility, carbon produced by photosynthesis accumulates in plant tissues, and the ratio between carbon and nitrogen (C:N) increases. Excess carbon is used in secondary metabolic pathways for synthesis of carbon-based defenses such as thorns and tannins. Conversely, increased soil nitrogen decreases the $\mathrm{C}: \mathrm{N}$ in plants' tissues, and plants must use carbon reserves to complement nitrogen for growth and reproduction. In the current study, the C:N ratio in leaves of sprouts was lower for burned plants compared to unburned plants. The carbon-nutrient balance hypothesis may be a better predictor of changes in physical and chemical antiherbivore defenses of blackbrush acacia and honey mesquite immediately after burning than hypotheses based on woody plant responses to tissue damage by browsing, especially if burning increases soil nutrients, inorganic soil nitrogen sources, and microbial nitrification (Aldous and Krefting 1946, Ahlgren 1960, Spencer and Chatelain 1953, Wright and Bailey 1982, Pyne et al. 1996).

Spinescence in blackbrush acacia, honey mesquite, and spiny hackberry appears to be ineffective at deterring herbivory, since less spinescent burned plants were not 
Table 4. Mean values ${ }^{1,2}$ of chemical defenses and nutrients in leaves of blackbrush acacia (Acacia rigidula Benth.), honey mesquite (Prosopis glandulosa Torr.), and spiny hackberry (Celtis pallida Torr.) averaged across 3 sampling periods in burned and unburned plots $(n=15)$ on the Rob and Bessie Welder Wildlife Foundation Refuge, San Patricio County, Tex., 1998.

\begin{tabular}{|c|c|c|c|c|c|}
\hline \multirow[b]{2}{*}{ Species } & \multicolumn{2}{|c|}{ Burned } & \multicolumn{2}{|c|}{ Unburned } & \multirow[b]{2}{*}{$\mathrm{P}$} \\
\hline & $\bar{x}$ & SE & $\bar{x}$ & SE & \\
\hline \multicolumn{6}{|l|}{ Blackbrush acacia } \\
\hline $\operatorname{NDF}(\%)^{3}$ & 35.89 & 1.16 & 34.22 & 0.86 & \\
\hline $\operatorname{ADF}(\%)$ & 28.78 & 1.11 & 26.12 & 0.71 & $<0.001$ \\
\hline $\operatorname{ADL}(\%)$ & 11.62 & 0.80 & 11.40 & 0.58 & 0.656 \\
\hline Crude protein $(\%)$ & 15.81 & 0.47 & 15.97 & 0.55 & 0.825 \\
\hline Digestible protein $(\%)$ & 3.25 & 0.43 & 3.93 & 0.60 & 0.355 \\
\hline Digestible dry matter $(\%)$ & 36.12 & 1.10 & 38.54 & 1.10 & 0.007 \\
\hline Digestible energy $(\%)$ & 35.27 & 1.09 & 37.67 & 1.09 & 0.007 \\
\hline Gross energy $\left(\mathrm{kcal} \mathrm{g}^{-1}\right)^{4}$ & 4.99 & 0.04 & 4.98 & 0.04 & \\
\hline Net energy $\left(\mathrm{kcal} \mathrm{g}^{-\mathrm{P}}\right)$ & 1.76 & 0.05 & 1.88 & 0.05 & 0.016 \\
\hline \multicolumn{6}{|l|}{ Honey mesquite } \\
\hline $\operatorname{NDF}(\%)^{3}$ & 38.46 & 1.53 & 37.34 & 1.59 & \\
\hline $\operatorname{ADF}(\%)$ & 26.78 & 1.28 & 27.25 & 1.64 & 0.478 \\
\hline $\operatorname{ADL}(\%)$ & 7.99 & 0.45 & 10.23 & 0.63 & $<0.001$ \\
\hline Crude protein $(\%)$ & 22.01 & 0.71 & 21.14 & 1.07 & 0.259 \\
\hline Digestible protein $(\%)$ & 16.51 & 0.66 & 15.70 & 0.98 & 0.276 \\
\hline Digestible dry matter $(\%)$ & 60.59 & 1.15 & 57.87 & 1.36 & $<0.001$ \\
\hline Digestible energy (\%) & 59.49 & 1.13 & 56.80 & 1.35 & 0.003 \\
\hline Gross energy $\left(\mathrm{kcal} \mathrm{g}^{-1}\right)^{4}$ & 5.00 & 0.04 & 5.02 & 0.03 & \\
\hline Net energy (kcal g ${ }^{-P}$ ) & 2.97 & 0.06 & 2.85 & 0.07 & 0.013 \\
\hline \multicolumn{6}{|l|}{ Spiny hackberry } \\
\hline $\operatorname{NDF}(\%)^{3}$ & 21.58 & 0.95 & 21.85 & 1.17 & \\
\hline $\operatorname{ADF}(\%)$ & 11.32 & 0.42 & 10.45 & 0.29 & 0.201 \\
\hline $\operatorname{ADL}(\%)$ & 2.58 & 0.19 & 2.48 & 0.07 & 0.843 \\
\hline Crude protein $(\%)$ & 26.60 & 0.74 & 22.58 & 0.82 & $<0.001$ \\
\hline Digestible protein $(\%)$ & 20.81 & 0.69 & 17.08 & 0.76 & $<0.001$ \\
\hline Digestible dry matter $(\%)$ & 75.60 & 0.60 & 75.80 & 0.33 & 0.813 \\
\hline Digestible energy $(\%)$ & 74.36 & 0.59 & 74.55 & 0.33 & 0.813 \\
\hline Gross energy $\left(\mathrm{kcal} \mathrm{g}^{-1}\right)^{4}$ & 4.25 & 0.04 & 4.17 & 0.04 & \\
\hline Net energy $\left(\mathrm{kcal} \mathrm{g}^{-9}\right)$ & 3.16 & 0.03 & 3.11 & 0.04 & 0.313 \\
\hline
\end{tabular}

Data were analyzed using analysis of variance (ANOVA) with repeated measures for a randomized complete block design with burning treatment and species as main effects and sampling period as the repeated measures factor.

${ }^{2}$ Values are based on leaf dry matter.

${ }^{3}$ Burning treatment by species interaction $(P=0.496)$ was not significant for NDF. Burning treatment main effect $(P=$ $0.230)$. sampling period by burning treatment interaction $(P=0.814)$. Sampling period by burning treatment by species interaction $(P=0.687)$.

${ }^{4}$ Burning treatment by species interaction $(P=0.180)$ was not significant for gross energy. Buming treatment main effect $(P=0.311)$. Sampling period by burning treatment interaction $(P=0.422)$. Sampling period by burning treatment by species interaction $(\mathrm{P}=0.509)$.

browsed more than unburned plants. Removing thorns did not change preference of blackbrush acacia or guajillo ( $A$. berlandieri Benth.) seedlings in cafeteriastyle feeding trials with tame white-tailed deer, but did increase utilization of seedlings of both species in a field study in Webb County where seedlings were available to wild herbivores, including black-tailed jackrabbits (Lepus californicus Gray) and white-tailed deer (Cash 2000). Although thorns may reduce foraging efficiency of large herbivores and acceptance of plants with a high thorn:leaf ratio (Cooper and Owen-Smith 1986, Belovsky and Schmitzet al. 1991, Gowda 1996), deer may consume large quantities of certain species by spending more time at those plants. Deer may also avoid thorns by foraging primarily on twig tips (Singer et al. 1994), where growth is occurring and thorns are soft.
In the current study, tannins were not induced or increased by burning, but high levels of protein-precipitating tannins in blackbrush acacia apparently are inherent in the species and can reduce digestibility of protein and other nutrients. Crude protein maintenance requirements for male white-tailed deer during antler growth and winter have been reported as low as $5.8 \%$ and $4.1 \%$, respectively (Asleson et al. 1996). Crude protein in blackbrush acacia plants $(16 \%)$ in burned plots in this study was well above maintenance levels, but tannins restricted digestible protein to about $3 \%$ based on a predictive equation (Robbins et al. 1987a, Hanley et al. 1992). Crude protein levels in blackbrush acacia leaves may be overestimated by the standard nitrogen-to-protein conversion factor (6.25), which assumes that all detectable nitrogen is bound in plant proteins. A recent study of 90 plant species in Singapore found that actual nitrogen-toprotein conversion factors ranged from 3.28 to 5.16 (Yeoh and Wee 1994). Nitrogen-to-protein conversion factors may be lower in certain south Texas shrub species such as blackbrush acacia and guajillo that contain high levels of non-protein nitrogen sources such as alkaloids and phenolic amines. Reduced digestibility caused by tannins may be a problem to white-tailed deer in areas of northeastern Mexico and southwest Texas where diets are composed of $>50 \%$ blackbrush acacia (Ramirez et al. 1996, Ramirez and Ledezma-Torres 1997). However, since these areas sustain successful white-tailed deer populations, deer may have adapted to tannins in shrubs. Proline-rich proteins

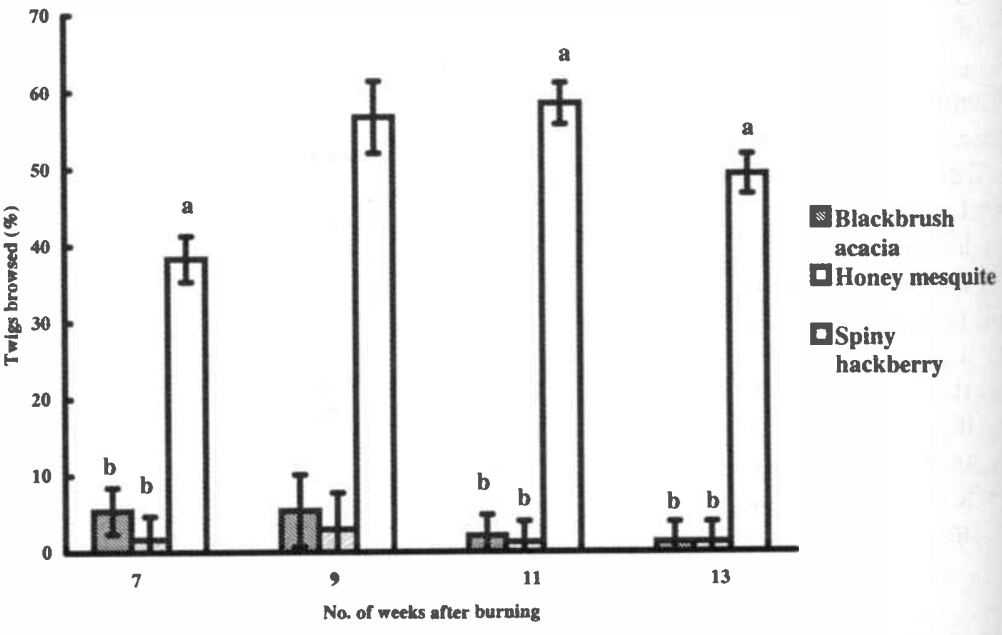

Fig. 4. Mean ( \pm SE) \% of twigs browsed by white-tailed deer (Odocoileus virginianus Raf.) of blackbrush acacia (Acacia rigidula Benth.), honey mesquite (Prosopis glandulosa Torr.), and spiny hackberry (Celtis pallida Torr.) in burned plots $(n=5)$ monitored biweekly during the period 7 to 13 weeks after burning in August 1998 on the Rob and Bessie Welder Wildlife Foundation Refuge, San Patricio County, Tex. Means within a week associated with the same letter are similar ( $P>0.05$, Tukey's HSD). 
that deactivate tannins have been reported in saliva of several herbivores that normally consume browse, including black bears (Ursus americanus Pallas), domestic rabbits (Oryctolagus cuniculus L.), mountain hares (L. timidus L.), mule deer ( $O$. hemionus Raf.), and rats (Rattus rattus $\mathrm{L}$.) (Austin et al. 1989, Mole et al. 1990, Robbins et al. 1991), and may reduce impacts that tannins have on browse digestibility.

Spiny hackberry grew, taller than honey mesquite, and blackbrush acacia grew as tall as honey mesquite after burning, contradicting the findings of Hamilton et al. (1981). Hamilton et al. (1981) did not protect spiny hackberry plants from whitetailed deer herbivory, which may explain why spiny hackberry appeared to grow more slowly than honey mesquite in their study. In the current study, intense browsing of spiny hackberry by white-tailed deer after burning suppressed sprout growth. The resource availability hypothesis suggests that plants adapted to highly fertile environments grow rapidly to escape herbivory and invest minimally into physical and chemical defenses (Bryant and Kuropat 1980, Coley et al. 1985, Bryant et al. 1989, Rohner and Ward 1997). Spiny hackberry's adaptation to highly fertile environments probably explains its ability to grow rapidly after burning. Honey mesquite often overcompensates for top growth removal by producing many sprouts after burning (Scifres and Hamilton 1993), possibly at the cost of attaining height. Additionally, Scifres and Hamilton (1993) reported that honey mesquite is stunted temporarily by summer burns.

Burning appears to be a desirable follow-up treatment to mowing. Not only does burning temporarily increase nutritional value of shrub sprouts, but it also decreases physical defenses and suppresses growth of shrub species that have low palatability to white-tailed deer. Additional research needs to be conducted to determine if decreased spinescence after burning is a long-term phenomenon. Burning after mowing may increase chemical defenses and decrease nutritional value in blackbrush acacia, which could be detrimental to white-tailed deer in areas where blackbrush acacia composes a large proportion of deer diets.

\section{Literature Cited}

Ahlgren, C. E. 1960. Some effects of fire on reproduction and growth of vegetation in northeastern Minnesota. Ecol. 41:431-445.
Aldous, S. E. and L. W. Krefting. 1946. The present status of moose on Isle Royale. Trans. North Amer. Wildl. Conf. 11:296-308.

Arnold, L. A., Jr. and D. L. Drawe. 1979. Seasonal food habits of white-tailed deer in the South Texas Plains. J. Range Manage. 32:175-178.

Asleson, M. A., E. C. Hellgren, and L. M. Varner. 1996. Nitrogen requirements for antler growth and maintenance in whitetailed deer. J. Wildl. Manage. 60:744-752.

Austin P. J., L. A. Suchar, C. T. Robbins, and A. E. Hagerman. 1989. Tannin-binding proteins in saliva of deer and their absence in saliva of sheep and cattle. J. Chem. Ecol. 15:1335-1346.

Basey, J. M., S. H. Jenkins, and P. E. Busher. 1988. Optimal central-place foraging by beavers: tree-size selection in relation to defensive chemicals of quaking aspen. Oecologia 76:278-282.

Belovsky, G. E. and O. J. Schmitz. 1991. Mammalian herbivore optimal foraging and the role of plant defenses, p. 1-28. In: R. T. Palo and C. T. Robbins (eds.) Plant defenses against mammalian herbivory. CRC Press, Inc., Boca Raton, Fla.

Box, T. W. and J. Powell. 1965. Brush management techniques for improved forage values in South Texas. Trans. North Amer. Wildl. Conf. 30:285-296.

Bryant, J. P. 1981. Phytochemical deterrence of snowshoe hare browsing by adventitious shoots of four Alaskan trees. Sci. 231:889-890.

Bryant, J. P. and P. J. Kuropat. 1980. Selection of winter forage by subarctic browsing vertebrates: the role of plant chemistry. Annu. Rev. Ecol. Syst. 11:261-285.

Bryant, J .P., F. S. Chapin III, and D. R. Klein. 1983. Carbon/nutrient balance of boreal plants in relation to vertebrate herbivory. Oikos 40:357-368.

Bryant, J. P., and P. J. Kuropat. 1980. Selection of winter forage by subarctic browsing vertebrates: the role of plant chemistry. Annu. Rev. Ecol. Syst. 11:261-285.

Bryant, J. P., and P. J. Kuropat, S. M. Cooper, K. Frisby, and N. Owen-Smith. 1989. Resource availability hypothesis of plant antiherbivore defence tested in a South African savanna ecosystem. Nature 340:227-229.

Byram, G. M. 1959. Combustion of forest fuels, p. 61-89. In: K. P. Davis (ed.), Forest fire: control and use. McGraw-Hill, New York, N.Y.

Campbell, B. M. 1986. Plant spinescence and herbivory in a nutrient poor ecosystem. Oikos 47:168-172.

Cash, V. W. 2000. Nutrient enrichment effects on anti-herbivore defenses and utilization by white-tailed deer of two sympatric Acacia species. M. S. Thesis, Texas A\&M University-Kingsville, Kingsville, Tex.

Clausen, T. P., F. D. Provenza, E. A. Burritt, J. P. Bryant, and P. B. Reichardt. 1990. Ecological implications of condensed tannin structure: a case study. J. Chem. Ecol. 16:2381-2392.
Coley, P. D., J. P. Bryant, and F. S. Chapin. 1985. Resource availability and plant antiherbivore defense. Sci. 230:895-899.

Cooper, S. M. and T. F. Ginnett. 1998. Spines protect plants against browsing by small climbing mammals. Oecologia 113:219-221.

Cooper, S. M. and N. Owen-Smith. 1985. Condensed tannins deter feeding by browsing ruminants in a South African savanna. Oecologia 67:142-146.

Cooper, S. M. and N. Owen-Smith. 1986. Effects of plant spinescence on large mammalian herbivores. Oecologia 68:446-455.

Cooper, S. M., N. Owen-Smith, and J. P. Bryant. 1988. Foliage acceptability to browsing ruminants in relation to seasonal changes in leaf chemistry of woody plants in a South African savanna. Oecologia 75:336-342.

Drawe, D. L., A. D. Chamrad, and T. W. Box. 1978. Plant communities of the Welder Wildlife Refuge. Welder Wildl. Found. Contr. No. 5, Ser. B, Revised. Sinton, Tex.

Everitt, J. H. 1983. Effects of plant shredding on nutrient content of four South Texas deer browse species. J. Range Manage. 36:779-781.

Fajer, E. D., M. D. Bowers, and F. A. Bazzaz. 1992. The effect of nutrients and enriched $\mathrm{CO}_{2}$ environments on production of carbon-based allelochemicals in plantago: a test of the carbon/nutrient balance hypothesis. Amer. Nat. 140:707-723.

Forbes, T. D. A., I. J. Pemberton, G. R. Smith, and C. M. Hensarling. 1995. Seasonal variation of two phenolic amines in Acacia berlandieri. J. Arid Environ. 30:403415.

Goering, H. K. and P. J. Van Soest. 1970. Forage fiber analysis (apparatus, reagents, procedures, and some applications). Agr. Handbook No. 379. USDA, ARS, Washington, D.C.

Gowda, J. H. 1996. Spines of Acacia tortilis: what do they defend and how? Oikos:77:279-284.

Guckian, W. J. and R. N. Garcia. 1979. Soil survey of San Patricio and Aransas counties, Texas. USDA, SCS, Washington, D.C.

Hagerman, A. E., C. T. Robbins, Y. Weerasuriya, T. C. Wilson, and C. McArthur. 1992. Tannin chemistry in relation to digestion. J. Range Manage. 45:57-62.

Hamilton, W. T., L. M. Kitchen, and C. J. Scifres. 1981. Height replacement of selected woody plants following burning or shredding. Tex. Agr. Exp. Sta. Bull. 1361, Tex. A\&M Univ, College Station, Tex.

Hanley, T. A., C. T. Robbins, A. E. Hagerman, and C. McArthur. 1992. Predicting digestible protein and digestible dry matter in tannin-containing forages consumed by ruminants. Ecol. 73:537-541.

Lundberg, P. and M. Àström. 1990. Low nutritive quality as a defense against optimally foraging herbivores. Amer. Natur. 135:547-561. 
Martin, J. S. and M. M. Martin. 1982. Tannin assays in ecological studies: Lack of correlation between phenolics, proanthocyanidins, and protein-precipitating constituents in mature foliage of six oak species. Oecologia 54:205-211.

Masters, R. E. and D. M. Engle. 1994. BEHAVE: Evaluated for prescribed fire planning in mountainous oak-shortleaf pine habitats. Wildl. Soc. Bull. 22:184-191.

Mattson, W. J. 1980. Herbivory in relation to plant nitrogen content. Annu. Rev. Ecol. Syst. 11:119-16.

Meyer, M. W., R. D. Brown, and M. W. Graham. 1984. Protein and energy content of white-tailed deer diets in the Texas coastal bend. J. Wildl. Manage. 48:527-534.

Milewski, A. V., T. P. Young, and D. Madden. 1991. Thorns as induced defenses: experimental evidence. Oecologia 86:70-75.

Milliken, G. A. and D. E. Johnson. 1984. Analysis of messy data. Vol. 1: Designed experiments. Lifetime Learning Publications, Belmont, Cal.

Mole, S., L. G. Butler, and G. Iason. 1990. Defense against dietary tannin in herbivores: A survey for proline-rich salivary proteins in mammals. Biochem. Syst. Ecol. 18:287-293.

Pyne, S. J., P. L. Andrews, and R. D. Laven. 1996. Introduction to wildland fire. Second edition. John Wiley and Sons, Inc., New York, N.Y.

Ramirez, R. G., and R. A. Ledezma-Torres. 1997. Forage utilization from native shrubs Acacia rigidula and Acacia farnesiana by goats and sheep. Small Ruminant Res. 25:43-50.

Ramirez, R. A., G. F. W. Haenlein, A. Trevino, and J. Reyna. 1996. Nutrient and mineral profile of white-tailed deer (Odocoileus virginianus texanus) diets in northeastern Mexico. Small Ruminant Res. 23:7-16.
Reynolds, J. P., T. E. Fulbright, and S. L. Beasom. 1992. Mechanical rejuvenation to dampen seasonal variation in chemical composition of browse. J. Range Manage. 45:589-592.

Robbins, C. T. 1993. Wildlife feeding and nutrition. Second edition. Academic Press, New York, N.Y.

Robbins, C. T., S. Mole, A. E. Hagerman, and T.A. Hanley. 1987b. Role of tannins in defending plants against ruminants: reduction in dry matter digestion. Ecology 68:16061614.

Robbins, C. T., A. E. Hagerman, P. J. Austin, C. McArthur, and T. A. Hanley. 1991. Variation in mammalian physiological responses to a condensed tannin and its ecological implications. J. Mammal. 72:480-486.

Robbins, C. T., T. A. Hanley, A. E. Hagerman, O. Hjeljord, D. L. Baker, C. C. Schwartz, and W. W. Mautz. 1987a. Role of tannins in defending plants against ruminants: reduction in protein availability. Ecol 68:98-107.

Robbins, C. T., S. Mole, A. E. Hagerman, and T.A. Hanley. 1987b. Role of tannins in defending plants against ruminants: reduction in dry matter digestion. Ecol. 68:1606-1614.

Rohner, C. and D. Ward. 1997. Chemical and mechanical defense against herbivory in two sympatric species of desert Acacia. J. Veg. Sci. 8:717-726.

Ruthven, D. C., and E. C. Hellgren. 1995. Root-plowing effects on nutritional value of browse and mast in south Texas. J. Range Manage. 48:560-562.

SAS Institute, Inc. 1989. SAS user's guide: statistics. 1989 edition. SAS Institute Inc. Cary, NC.
Schindler, J. R. 2000. Role of spinescence and secondary compounds in white-tailed deer preference of shrubs in burned and mowed areas in South Texas. M. S. Thesis, Texas A\&M University-Kingsville, Kingsville, Tex.

Scifres, C. J. and W. T. Hamilton. 1993. Prescribed burning for brushland management: The south Texas example. Texas A\&M University Press, College Station, Tex.

Singer, F. J., L. C. Mark, and R. C. Cates. 1994. Ungulate herbivory of willows on Yellowstone's northern winter range. J. Range Manage. 47:435-443.

Spencer, D. L. and E. F. Chatelain. 1953. Progress in the management of the moose of south central Alaska. Trans. N. Amer. Wildl. Conf. 18:539-552.

Stock, W. D., D. LeRoux, and F. Van der Heyden. 1993. Regrowth and tannin production in woody and succulent karoo shrubs in response to simulated browsing. Oecologia 96:562-568.

Woodward, A. and D. L. Coppock. 1995. Role of plant defense in the utilization of native browse in southern Ethiopia. Agrofor. Syst. 32:147-161.

Wright, H. A., and A. W. Bailey. 1982. Fire ecology: United States and Canada. John Wiley and Sons, Inc., New York, N.Y.

Yeoh, H. and Y. Wee. 1994. Leaf protein contents and nitrogen-to-protein conversion factors for 90 plant species. Food Chem. 49:245-250.

Young, T. P. 1987. Increased thorn length in Acacia depranolobium - an induced response to browsing. Oecologia 71:436-438. 